\title{
THE EFFECT OF HORMONAL CONTRACEPTION ON BODY MASS INDEX AMONG WOMEN IN REPRODUCTIVE AGE
}

\author{
Widya Kusumawati, Lely Khulafa'ur Rosidah \\ Dharma Husada Academy of Midwifery, Kediri, East Java
}

\begin{abstract}
Background: Hormonal contraception is still a popular contraceptive method for most women. More than six million women worldwide use the injectable hormonal contraceptive method. The hormones estrogen and progesterone contained in hormonal birth control can affect the increase of sodium and fluids. This will affect the fat layer and appetite which will cause weight gain, thus impacting body mass index (BMI). This study aimed to determine the effect of hormonal contraception on BMI.

Subjects and Method: This was a cross-sectional study conducted in Ngampel village, Mojoroto District, Kediri, East Java, in June - July 2019. The total of 30 women in reproductive age were selected using purposive sampling technique. The independent variable was the use of hormonal contraception. the dependent variable was BMI. The data were collected by questionnaire then analyzed using Chi Square test.

Results: The use of hormonal contraception was increased the BMI among women in reproductive age.

Conclusion: The use of hormonal contraception can give an effect on BMI. Sometimes, woman body should be given the opportunity to rest using non-hormonal birth control.
\end{abstract}

Keywords: family planning, hormonal contraception, body mass index

\section{Correspondence:}

Widya Kusumawati. Dharma Husada Kediri Academy of Midwifery. Jl. Coverage No 41 A Kediri

City. Email: widya.koesoemawati@gmail.com. Mobile: 085722223910. 